\title{
The instrument for determining the levels of reflective thinking among elementary school students
}

\author{
Bilge TAŞKIN CAN ${ }^{*}$ and Cennet YILDIRIM ${ }^{2}$ \\ ${ }^{1}$ Pamukkale University, Denizli, Turkey. \\ ${ }^{2}$ Atatürk Elementary School, Sarıgöl, Manisa, Turkey.
}

Accepted 24 December, 2013

\begin{abstract}
The purpose of this research is to develop a reliable and valid instrument in order to determine the elementary school students' levels about reflective thinking. A total of 320 students of $^{\text {th }}, 7^{\text {th }}$ and $8^{\text {th }}$ grades from 6 different primary schools participated in the study. It was identified that the instrument was composed of totally 17 items with one factor and the whole instrument has a reliability coefficient of Cronbach $\alpha=0.86$. At the same time, this instrument is also the first original instrument developed for determining the elementary school students' levels of reflective thinking in Turkey.
\end{abstract}

Key words: Elementary students, reflective thinking, science education.

\section{INTRODUCTION}

Science is not only a total of facts about the earth, but also a way of thinking and continuous research based on experimental criteria, logical thinking and inquiry. Scientific methods include the processes of observation, hypothesis building, testing, data collection, data interpretation, and presentation of findings. Imagination, creativity, openness to new ideas, mental objectivity and inquiry are very important in scientific studies. Therefore, in the teaching of science and technology, the goal is learning to reach accurate information of individuals through directly discovery, revised in view of the world and the configuration and gradually learning to develop enthusiasm for learning (MEB, 2005). Individuals must gain experience to reach accurate information through discovery. But gaining experience alone will not be enough, because we are expected to reach scientific knowledge through experience from individuals. It is possible to reflect on the experience. In this way, individuals will know what, why and how they do something and will discover scientific knowledge on their own.

One of the most important conceptions of century and qualifications that individuals need to have is life-long learning skill. Life-long learning skills require using reflective thinking skills and adapting learning to new situations with a flexible manner for making knowledge understandable (Herrington and Oliver, 2002; cited in Kızılkaya, 2009).

'Reflective Thinking' has been defined in different ways by different researchers. The studies showed that John Dewey took the most attribution in this regard. Therefore, researcher found it appropriate to give place to the definition of Dewey first.

Dewey (1933) defined reflective thinking as the kind of thinking that consists of turning a subject over in the mind and giving it serious consideration. Dewey (1933) indicated that reflection is a kind of special thinking and it includes doubt, hesitation, confusion and making inquiries and researches to resolve this confusion. The request of resolving this confusion guides the process of reflection. The basis of reflective thinking is based on John Dewey's (1933) approach, learning by doing by living.

Taggart and Wilson (1998) defined reflective thinking as a process of making logical decisions on education issues, and then assessing the decisions made by teachers. Ross (1989) has stated that reflective thinking 
is making rational choices and a way of thinking about educational issues that require taking responsibility for these choices (cited in Taggart and Wilson, 1998). Unver (2003) defines reflective thinking as a process of thinking on solving problems and raising the positive and negative situations about the level and teaching or learning method of individual.

In recent years, in the United States of America, many commissions, boards and foundations like National Board of Professional Teaching Standards (NBPTS); National Commission on Teaching and America's Future (NCTAF); the National Foundation for the Improvement of Education (NFIE); the National Staff Development Council (NSDC) and state and local school districts have identified reflection as a standard that all teachers and students must strive to follow.

The following six phases of reflection have been identified by Rodgers. He says that these phases are also for students' systematically thinking.

\section{I. an experience,}

II. spontaneous interpretation of the experience,

III. naming the problems or the questions that arise out of the experience,

IV. Generating possible explanations for the problem or questions posed,

V. ramifying the explanations into full-blown hypotheses, VI. Testing or experimenting the selected hypothesis (Rodgers, 2002).

Dewey (1933) refers to three attitudes to develop reflective thinking:

1. open-mindedness

2. whole-heartedness

3. responsibility

Open-mindedness can be described as freedom from prejudice, partisanship, and close to the mind to entertain new ideas. Open-mindedness requires to pay attention to alternative possibilities and to listen actively to the other side.

Whole-heartedness arises when someone is thoroughly interested in some object and cause. When a person is interested in a topic, he devotes himself to it.

Responsibility can be described as consideration of the results of the steps of the project and be willingness to adapt the results (Dewey, 1933).

In Turkey, the studies aim to identify the students' reflective thinking levels - those either adapting the existing instruments into Turkish or developing original instruments; they all address the reflective thinking levels of teachers and preservice teachers. However, there has not been such an instrument developed towards the reflective thinking levels of the elementary students in Turkey. The basic point of this study is the absence of such an instrument towards Turkish elementary students.
The purpose of the study is to develop a valid and reliable instrument about the reflective thinking levels of elementary students.

\section{METHOD}

The following steps in the process of the development of the instrument of reflective thinking are used: preparation of the items of the instrument, having experts' views about the items for the scope validity, pilot study, the analysis of construct validity and reliability.

\section{Preparation of the Items of the Instrument}

While the items of the instrument are being determined, the researcher has benefitted from studies and instruments made previously for undergraduated students in the literature. Items in the instrument have been constituted in 5 point Lykert type, with range from "strongly disagree"(1) to "completely agree"(5). While the items of the instrument are being prepared, the researcher has considerated the language used in the instrument that is simple and understandable.

Scope Validity

Scope validity is the degree of representation of topics that measurement tool intended to measure or items and questions in the measuremnet tool in a balanced way (Cronbach, 1990; cited in Tavşancıl, 2006). To ensure the scope validity of the instrument, three faculty members that were experts in their fields, that is science and technology teachers have been asked about the items in the instrument and the suitability of the subject the instrument measured. In the light of suggestions, some of the items in the instrument have been eliminated, and some of the the items in the instrument have been corrected; at the end the instrument has been prepared for the pilot study. At the beginning, the instrument prepared for the pilot study consisted of 35 items and 12 of the items in the instrument are negative.

\section{Pilot study}

The studies of the development of the instrument were done with the data obtained from a total of 333 students in 6th, 7th and 8th grades of the elementary schools near the province of Denizli of different socio-economic regions; they were chosen by dispropartionate element selecting sampling method. A total of 13 students' data filled out superficially and marked in an incorrect way were excluded from the scope of the study. The studies of reliability of the instrument have been obtained from 320 students. Information about the sanpling is presented in Table 1.

\section{Data analysis}

The analysis of the data obtained was done by using SPSS 11.5 packet programme. In the analysis, exploratory factor analysis, correlation analysis, cronbach alpha internal consistency and descriptive static techniques were used.

\section{RESULTS}

In this part, reliability analysis and exploratory factor analysis on construct validity of the instrument were 
Table 1. Sample charecteristics.

\begin{tabular}{cccc}
\hline & \multicolumn{2}{c}{ Gender $(\mathbf{n}=$ number $)$} & Total \\
\hline Class & Female & Male & (n=number) \\
\hline 6. & 59 & 60 & 119 \\
7. & 42 & 55 & 97 \\
8. & 58 & 46 & 104 \\
Total & 159 & 161 & 320 \\
\hline
\end{tabular}

Table 2. The results of the factor analysis

\begin{tabular}{lc}
\hline Item no & Factor load value \\
\hline 1 & .580 \\
6 & .549 \\
9 & .618 \\
10 & .562 \\
12 & .513 \\
14 & .507 \\
15 & .589 \\
17 & .506 \\
18 & .600 \\
19 & .649 \\
21 & .633 \\
24 & .497 \\
26 & .476 \\
28 & .488 \\
29 & .539 \\
32 & .618 \\
33 & .590 \\
\hline
\end{tabular}

billeted.

\section{Determining construct validity}

Construct validity of an instrument may be determined by factor analysis and internal consistency. Factor analysis is clustering the properties of measured structure showing a high correlation with each other under a factor. Internal consistency is testing conjecture to know whether the measured structure is homogenous or not (Tavşancıl, 2006). To determine which sub-structures comprise reflective thinking levels exploratory factor analysis was used to ensure construct validity. Exploratory factor analysis is defined as investigation in which the researcher has not got any information on the number of factors that the measurement tool measures; rather than a specific hypothesis to test and trying to obtain information about the nature of the measurement tool and measured factors (Crocker and Algina, 1986; cited in Tavşancıl, 2006). Before the analysis, to determine whether sampling is suitable for factor analysis, Kaiser-
Meyer-Olkin (KMO) and Barlett tests have been applied. The value of $\mathrm{KMO}$ test is 0.84 which can be placed in 0.80-0.89 range (very good) defined by Kaiser (cited in Tavşancıl, 2006). The value of Barlett test has been found significant $\left(x^{2}=3102 ; p=0.00\right)$. The results of $\mathrm{KMO}$ and Barlett tests have shown that the data are suitable for factor analysis.

At the beginning, the items of the instrument consisting of 35 items are located under only one factor (the difference between the two highest load value is at least 0.10 ) and the value of the factor load located under the factor is high ( 0.40 and above); 18 items that are not suitable for these qualifications have been sorted out from the instrument (Tavşancıl, 2006). Finally, the instrument was reduced only to 17 items. The values of the factor load of 17 items are presented in Table 2.

At the end of the analysis, the instrument of reflective thinking levels is composed of one factor. The items in the one factor are presented in Table 3.

Item- total correlation has been calculated on the basis of total points and items to measure the internal consistency of the given instrument. In addition, the points that got the lowest and the highest scores from all of the instrument have been calculated. The results of this analysis are presented in Table 4.

According to Table 4, the item-total correlations of the instrument ranged from 0.49 to 0.63 . On the basis of both item and factor the obtained coefficients of the item-test correlation have not been found negative, zero or close to zero (Tavşancıl, 2006); it can be said that the internal consistency of the tool is high and so has got construct validity.

The final version of the obtained instrument consists of 17 items and it has been prepared in 5 point Lykert type. The highest point is 85 and the lowest point is 17 .

When the standard deviation of the points of the items was examined, it was found that the standard deviation of the items has got values ranging from 0.86 to 1,63 .

Reliability

Reliability is an indicator that the measurement tool measures the charecteristics with stability and without error (Tekin, 2000). The reliability of the instrument has been obtained by calculating Cronbach's a coefficient, which is 0.86 (Table 5).

According to these results, when the coefficiency reliability is 0.70 and above the instrument may be considered as reliable, (Nunnally, 1978; cited in Tavşancıl, 2006); the instrument (0.86) is reliable.

\section{DISCUSSION}

In this study, the development process of the instrument to determine elementary school students' Reflective Thinking levels has been discussed. At the end of the study, the reliable instrument consists of one factor and 17 items and its Cronbach a coefficient is 0.86 . We have 
Table 3. Items listed in the Instrument.

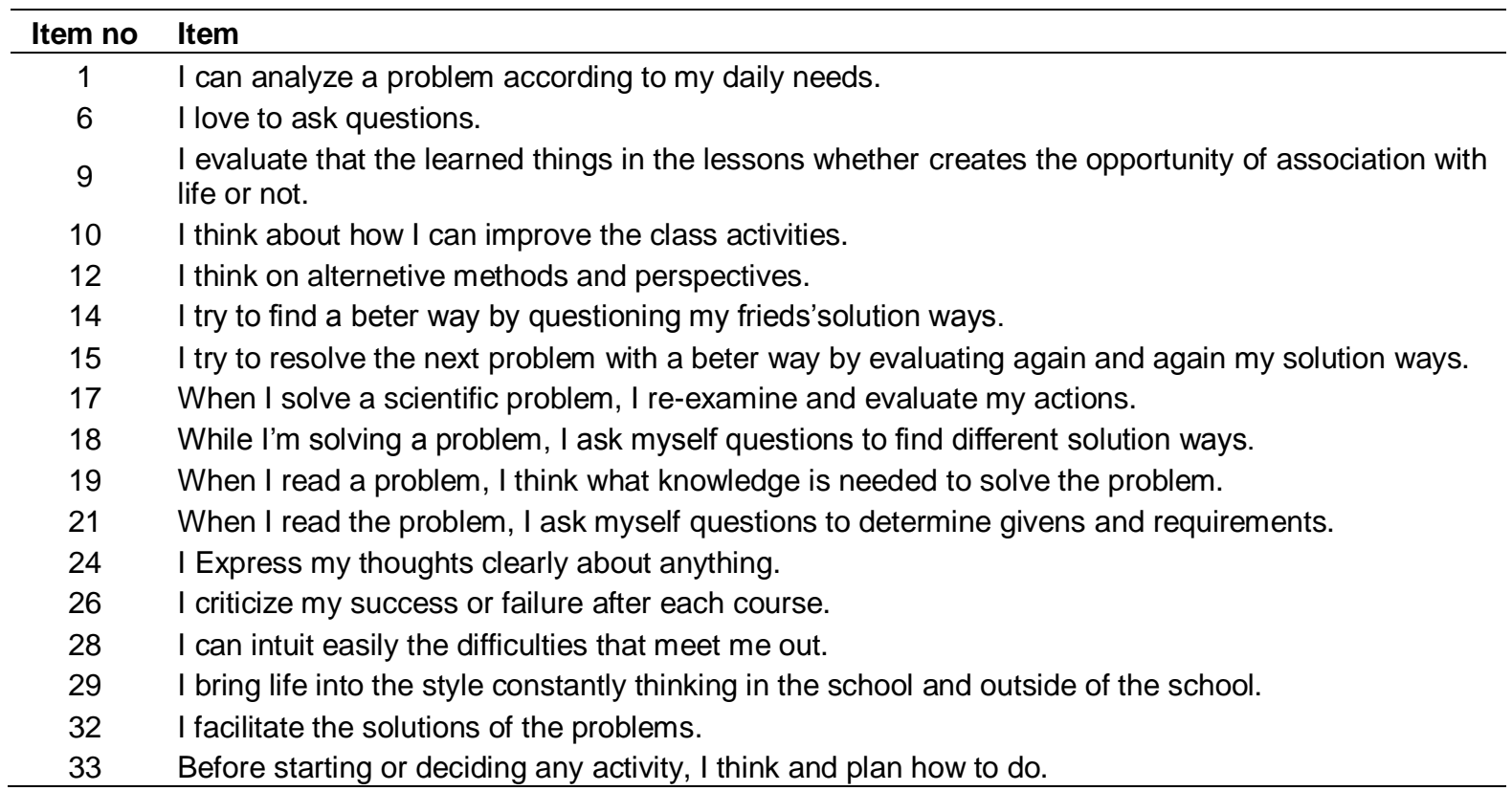

Table 4. Item and test statics and descriptive statistics.

\begin{tabular}{lcc}
\hline Item no & Item-test correlation & Standard deviation \\
\hline 1 & $0.565^{*}$ & 0.865 \\
6 & $0.551^{*}$ & 1.017 \\
9 & $0.612^{*}$ & 1.149 \\
10 & $0.551^{*}$ & 0.936 \\
12 & $0.520^{*}$ & 1.129 \\
14 & $0.515^{*}$ & 1.139 \\
15 & $0.585^{*}$ & 1.057 \\
17 & $0.516^{*}$ & 1.155 \\
18 & $0.593^{*}$ & 1.077 \\
19 & $0.635^{*}$ & 1.017 \\
21 & $0.627^{*}$ & 1.098 \\
24 & $0.514^{*}$ & 1.118 \\
26 & $0.495^{*}$ & 1.147 \\
28 & $0.500^{*}$ & 1.040 \\
29 & $0.545^{*}$ & 1.163 \\
32 & $0.612^{*}$ & 1.102 \\
33 & $0.580^{*}$ & 1.025 \\
Total & 1 & 10.19 \\
\hline
\end{tabular}

Table 5. The value of the Cronbach a of the reflective thinking instrument

\begin{tabular}{lcc}
\hline & $\mathbf{n}$ & Total \\
\hline Cronbach $\alpha$ & 320 & 0.86 \\
\hline
\end{tabular}

not compared the findings of the present study with similar findings of other studies because they are no studies on determining elementary school students' levels of reflective thinking.

The most recent science and technology curriculum has been prepared according to the constructivist approach. This approach requires the students to learn by doing and experiencing and sense knowledge themselves. It means that the students should learn by gaining experience; in this process when the students construct scientific knowledge by researching and inquirying, they 
should reflect on their own learning.

In science and technology lessons, we are trying to enage students with the scientific process skills, because we are expecting to resolve their problems by acting as a scientist in the problems they meet in daily laife. It is possible by producing alternative solutions to problems and doing reflection in this process. As a result, reflective thinking is an important skill which needs to be evaluated and improved.

This instrument which is valid and reliable for obtaining results is the first instrument developed for determining the reflective thinking of the elementary school students in our country.

The developed instrument can be used by researchers that are interested in the subject area as it is a valid and reliable instrument. Items are simple, clear and understandable; these facilitate the applicability of the instrument. The instrument with these characteristics may be used by science and technology teachers for determining students' reflective thinking in this area before and after the process of teaching and learning. In addition with this developed instrument, elementary students' reflective thinking levels can be examined by considering depth in terms of different variables (socio-economic level, gender, learning approaches etc.).

\section{REFERENCES}

Alp S (2007). The perspectives of Primary School Teachers on Reflective Thinking. Master Dissertation. 18 March University. Social Sciences Institute. Canakkale.

Crocker L, Algina J (1986) Introduction to Classical and Modern Test Theory, Harcourt Brace Jovanovich College Publishers: Philadelphia.

Dewey J (1933). How we Think. Boston. MA:Houghton Mifflin Company.

Dolapçıoğlu DS (2007). Evalution of Reflective Thinking Level of Preservice Teachers. Master Dissertation. Mustafa Kemal University. Social Sciences Institute. Hatay.

Filiz Y (2008). The Attitudes of Teachers As a Foreign Language Towards Reflective Teaching. Master Dissertation. Uludağ University. Social Sciences Institute. Bursa.
Güney K (2008). The Effect of Micro-Reflective Teaching Method in Accordance With the Presentation performance and Reflective Thinking Activities of Student Teachers. Doctoral Dissertation. Firat University. Social Sciences Institute. Elazığ.

Herrington J, Oliver R (2002). Designing for reflection in online courses. In Quality Conversations, Proceedings of the 25th HERDSA Annual Conference pp.313-329.

İnönü Y (2006). The Levels of History Teachers Ownership of the Properties of Reflective Thinking: Van Instance. Master Dissertation. The Hundredth Year University. Social Sciences Institute. Van.

Kızılkaya G (2009). The Effect of Web-Based Learning Enviroments Supported with Reflective Thinking Activities to Problem Solving. Doctoral Dissertation. Hacettepe University. Department of Computer Education and Instructional Technologies. Ankara.

Köksal N (2006). The Contributions of Reflective Thinking to PreService Teachers Teaching Practice. Unpublished Doctoral Dissertation. Hacettepe University. Social Sciences Institute. Ankara.

Ministry of Education (2005). The Curriculum of Elementary Science and Technology Lesson.

Rodgers C (2002). Defining Reflection: Another Look At John Dewey and Reflective Thinking. Teachers College Record 104(4), 842-866.

Ross DD (1989). First steps in developing a reflective approach. J. Teacher Educ. 40(2):22-30.

Savran A (2008). Professional Development of Preservice Biology Teachers Through Reflective Thinking. Doctoral Dissertation. ODTÜ.

Taggart L, Wilson P (1998). Promoting Reflective Thinking İn Teachers: 44 Action Strategies. Corwin Press, Inc.

Tavşancıl E (2006). Measurement of Attitudes and Data Analysis With SPSS. Nobel Press. 3th Print. Ankara.

Ünver, G. (2003). Reflective Thinking. (1th Print). Ankara: Pegema Press.

Yorulmaz M (2006). Evaluation of Primary School Teachers' View and Practices Relating to the Reflective Thinking. Master Dissertation. Fırat University. Social Sciences Institute. Elazığ. 
Appendix 1.

\begin{tabular}{|c|c|c|c|c|c|c|}
\hline \multicolumn{7}{|c|}{ Reflective Thinking Instrument for Elementary School Students } \\
\hline 1. & I can analyze a problem according to my daily needs. & 1 & 2 & 3 & 4 & 5 \\
\hline 2. & I love to ask questions. & 1 & 2 & 3 & 4 & 5 \\
\hline \multicolumn{2}{|r|}{$\begin{array}{l}\text { 3. I evaluate that the learned things in the lessons whether creates the opportunity } \\
\text { of association with life or not. }\end{array}$} & 1 & 2 & 3 & 4 & 5 \\
\hline 4. & I think about how I can improve the class activities. & 1 & 2 & 3 & 4 & 5 \\
\hline 5. & I think on alternetive methods and perspectives. & 1 & 2 & 3 & & 5 \\
\hline \multirow{2}{*}{ 6. } & \multirow{2}{*}{$\begin{array}{l}\text { I try to find a beter way by questioning my frieds'solution ways. } \\
\text { I try to resolve the next problem with a beter way by evaluating again and again }\end{array}$} & 1 & 2 & 3 & 4 & 5 \\
\hline & & 1 & 2 & 3 & 4 & 5 \\
\hline \multirow{2}{*}{$\begin{array}{l}8 . \\
9 . \\
\text { ways. }\end{array}$} & \multirow{2}{*}{$\begin{array}{l}\text { When I solve a problem, I re-examine and evaluate my actions. } \\
\text { While I'm solving a problem, I ask myself questions to find different solution }\end{array}$} & 1 & 2 & 3 & 4 & 5 \\
\hline & & 1 & 2 & 3 & 4 & 5 \\
\hline \multirow{2}{*}{$\begin{array}{l}10 . \\
11 . \\
\text { require }\end{array}$} & \multirow{2}{*}{$\begin{array}{l}\text { When I read a problem, I think what knowledge is needed to solve the problem. } \\
\text { When I read the problem, I ask myself questions to determine givens and } \\
\text { ents. }\end{array}$} & 1 & 2 & 3 & 4 & 5 \\
\hline & & 1 & 2 & 3 & 4 & 5 \\
\hline \multirow{6}{*}{$\begin{array}{l}12 . \\
13 . \\
14 . \\
15 . \\
\text { school. } \\
16 . \\
17 .\end{array}$} & \multirow{4}{*}{$\begin{array}{l}\text { I Express my thoughts clearly about anything. } \\
\text { I criticize my success or failure after each course. } \\
\text { I can intuit easily the difficulties that meet me out. } \\
\text { I bring life into the style constantly thinking in the school and outside of the }\end{array}$} & 1 & 2 & 3 & 4 & 5 \\
\hline & & 1 & 2 & 3 & 4 & 5 \\
\hline & & 1 & 2 & 3 & 4 & \\
\hline & & 1 & 2 & 3 & 4 & 5 \\
\hline & I facilitate the solutions of the problems. & 1 & 2 & 3 & 4 & 5 \\
\hline & Before starting or deciding any activity, I think and plan how to do. & 1 & 2 & 3 & 4 & 5 \\
\hline
\end{tabular}

Appendix 2. The Turkish Version of the Instrument.

Yansıtıcı Düşünme ile ilgili beceriler

1. Günlük intiyaçlarıma göre bir problemi analiz edebilirim (çözümleyebilirim).

2. Soru sormayı severim.

3. Derslerde öğrendiklerimin yaşamla ilişkilendirme fırsatı yaratıp yaratmadığını

değerlendiririm.

4. Dersteki etkinlikleri nasıl geliştirebileceğimi düşünürüm.

5. Alternatif yöntemler ve bakış açıları üzerinde düşünürüm.

6. Arkadaşlarımın çözüm yollarını sorgulayarak daha iyi bir yol bulmaya çalışırım.

7. Çözüm yollarımı tekrar tekrar değerlendirip bir sonraki problemi daha iyi çözmeye

çalışırım.

8. Bir problemi çözdüğümde yaptığım işlemleri tekrar inceler, değerlendiririm.

9. Problem çözerken, farklı çözüm yolları bulmak için kendime sorular sorarım.

10. Bir problemi okuduğumda çözüm için hangi bilgiye ihtiyacım olduğunu düşünürüm.

11. Problemi okuduğumda verilen ve istenenleri belirlemek için kendime sorular

11. sorarım.

12. Herhangi bir şey hakkındaki düşüncelerimi açıkça ifade ederim.

13. Her dersten sonra basarı ve başarısızlığımın kritiğini yaparım.

14. Karsıma çıkan zorlukları kolayca sezebilirim.

15. Okulda ve okul dışında sürekli düşünmeyi hayat tarzı haline getiririm.

16. Problemlerin çözümünü kolaylaştırırım.

17. Herhangi bir etkinliğe başlamadan ya da karar vermeden önce nasıl yapacağımı

17. düşünür ve planlarım.

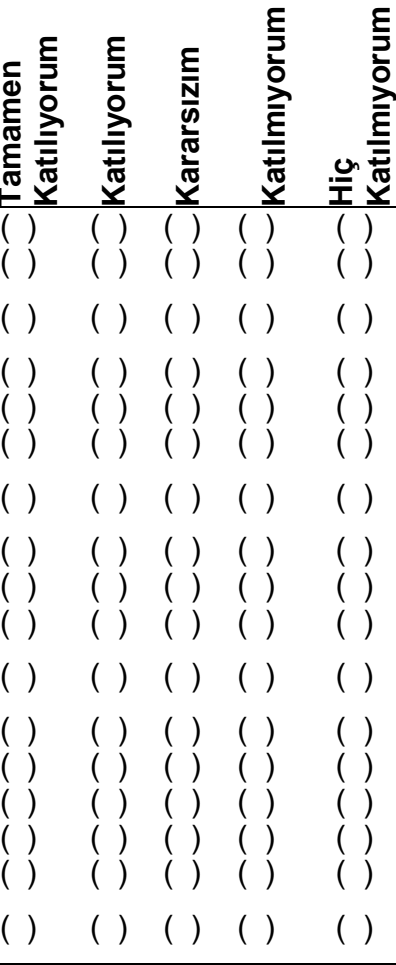


Appendix 3. The pilot study version of the Instrument.

\begin{tabular}{|c|c|c|c|c|c|c|}
\hline \multicolumn{2}{|r|}{ Reflective Thinking Instrument for Elementary School Students } & \multirow{2}{*}{$\frac{1}{(\mathrm{l})}$} & \multirow{2}{*}{$\begin{array}{ll}2 \\
(()\end{array}$} & \multirow{2}{*}{$\begin{array}{ll}3 \\
(1)\end{array}$} & \multirow{2}{*}{$\begin{array}{ll}4 \\
()\end{array}$} & \multirow{2}{*}{$\begin{array}{ll}5 \\
(1)\end{array}$} \\
\hline 1. & 1. I can analyze a problem according to my daily needs. & & & & & \\
\hline 2. & I look for evidence that support or refute my desicion. & ( ) & ( ) & ( ) & ( ) & ( ) \\
\hline 3. & I can not assess different aspects of events. & ( ) & ( ) & ( ) & ( ) & ( ) \\
\hline 4. & My behaviour depends on the position of the problem. & ( ) & ( ) & ( ) & ( ) & ( ) \\
\hline 5. & I'm not flexible in my thoughts. & ( ) & ( ) & ( ) & ( ) & ( ) \\
\hline 6. & I love to ask questions. & ( ) & ( ) & ( ) & ( ) & ( ) \\
\hline 7. & I'm open to criticism from my friends. & ( ) & ( ) & ( ) & ( ) & ( ) \\
\hline 8. & I can not associate with previous and next topic. & ( ) & ( ) & ( ) & ( ) & ( ) \\
\hline 9. & $\begin{array}{l}\text { I evaluate that the learned things in the lessons whether creates the opportunity of } \\
\text { association with life or not. }\end{array}$ & ( ) & ( ) & ( ) & ( ) & ( ) \\
\hline 10. & $\begin{array}{l}\text { I evaluate that the learned things in the lessons whether creates the opportunity of } \\
\text { association with life or not. }\end{array}$ & ( ) & ( ) & ( ) & ( ) & ( ) \\
\hline 11. & I don't think that I could learn how differently the same subject. & ( ) & ( ) & ( ) & ( ) & ( ) \\
\hline 12. & I think on alternetive methods and perspectives. & ( ) & ( ) & ( ) & ( ) & ( ) \\
\hline 13. & I don't find adequate ptactices in the book. & ( ) & ( ) & ( ) & ( ) & ( ) \\
\hline 14. & I try to find a beter way by questioning my frieds'solution ways. & ( ) & ( ) & ( ) & ( ) & ( ) \\
\hline 15. & $\begin{array}{l}\text { I try to resolve the next problem with a beter way by evaluating again and again } \\
\text { my solution ways. }\end{array}$ & ( ) & ( ) & ( ) & ( ) & ( ) \\
\hline 16. & When solving problems, I don't think about why I'm doing what process. & ( ) & ( ) & ( ) & ( ) & ( ) \\
\hline 17. & When I solve a problem, I re-examine and evaluate my actions. & ( ) & ( ) & ( ) & ( ) & ( ) \\
\hline 18. & While I'm solving a problem, I ask myself questions to find different solution ways. & ( ) & ( ) & ( ) & ( ) & ( ) \\
\hline 19. & When I read a problem, I think what knowledge is needed to solve the problem. & ( ) & ( ) & ( ) & ( ) & $($ ( ) \\
\hline 20. & $\begin{array}{l}\text { When I read a problem, I don't interrelate between the similarities and differences } \\
\text { about previously solved problems by thinking. }\end{array}$ & ( ) & ( ) & ( ) & ( ) & ( ) \\
\hline 21. & $\begin{array}{l}\text { When I read the problem, I ask myself questions to determine givens and } \\
\text { requirements. }\end{array}$ & ( ) & ( ) & ( ) & ( ) & ( ) \\
\hline 22. & I do not know how to deal with difficulties and negativity. & ( ) & ( ) & ( ) & ( ) & ( ) \\
\hline 23. & I can evaluate myself at the end of the course. & ( ) & ( ) & ( ) & ( ) & ( ) \\
\hline 24. & $\begin{array}{l}\text { When I read the problem, I ask myself questions to determine givens and } \\
\text { requirements. }\end{array}$ & ( ) & ( ) & ( ) & ( ) & ( ) \\
\hline 25. & I give the opportunity to criticize me to the people around. & ( ) & ( ) & ( ) & ( ) & ( ) \\
\hline 26. & I criticize my success or failure after each course. & ( ) & ( ) & ( ) & ( ) & ( ) \\
\hline 27. & I don't look evets from different perspectives. & ( ) & ( ) & ( ) & ( ) & ( ) \\
\hline 28. & I can intuit easily the difficulties that meet me out. & ( ) & ( ) & ( ) & ( ) & ( ) \\
\hline 29. & I bring life into the style constantly thinking in the school and outside of the school. & ( ) & ( ) & ( ) & ( ) & ( ) \\
\hline 30. & I do not care what, when, how and why I'm doing. & ( ) & ( ) & ( ) & ( ) & ( ) \\
\hline 31. & I do not know how I find necessary information on any subject. & ( ) & ( ) & ( ) & ( ) & ( ) \\
\hline 32. & I facilitate the solutions of the problems. & ( ) & ( ) & ( ) & ( ) & ( ) \\
\hline 33. & Before starting or deciding any activity, I think and plan how to do. & ( ) & ( ) & ( ) & ( ) & ( ) \\
\hline 34. & I don't associate new learned knowledge with previous experiences. & ( ) & ( ) & ( ) & ( ) & ( ) \\
\hline 35. & I write my thoughts on the subject at the end of the course. & ( ) & ( ) & ( ) & ( ) & ( ) \\
\hline
\end{tabular}

Appendix 4. The Turkish version of the pilot study.

Yansıtıcı Düşünme ile ilgili beceriler

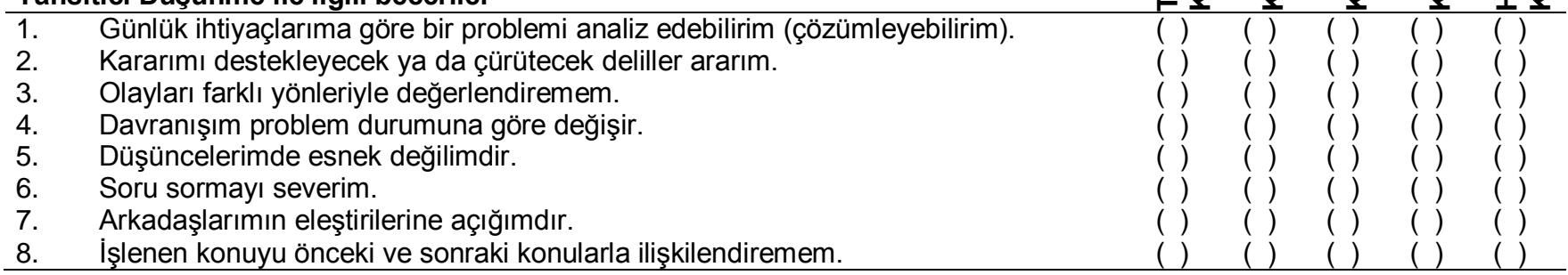


Appendix 4. Contd.

9. Derslerde öğrendiklerimin yaşamla ilişkilendirme fırsatı yaratıp yaratmadığını

10. Dersteki etkinlikleri nasıl geliştirebileceğimi düşünürüm.

11. Aynı konuyu daha farklı nasıl öğrenebileceğimi düşünmem.

12. Alternatif yöntemler ve bakış açıları üzerinde düşünürüm.

13. Kitaptaki etkinliklerle yetinmem.

14. Arkadaşlarımın çözüm yollarını sorgulayarak daha iyi bir yol bulmaya çalışırım.

15. Çözüm yollarımı tekrar tekrar değerlendirip bir sonraki problemi daha iyi çözmeye

15. çalışırım.

16. Problem çözerken, hangi işlemi neden yaptığımı düşünmem.

17. Bir problemi çözdüğümde yaptığım işlemleri tekrar inceler, değerlendiririm.

18. Problem çözerken, farklı çözüm yolları bulmak için kendime sorular sorarım.

19. Bir problemi okuduğumda çözüm için hangi bilgiye ihtiyacım olduğunu düşünürüm.

20. Bir problemi okuduğumda daha önce çözdüğüm problemleri düşünerek benzerlik ve farklılıklarına göre aralarında ilişki kurmam.

21. Problemi okuduğumda verilen ve istenenleri belirlemek için kendime sorular 21. sorarım

22. Olumsuzluklar ve zorluklarla nasıl baş edeceğimi bilemem.

23. Dersin sonunda kendimi değerlendirebilirim.

24. Herhangi bir şey hakkındaki düşüncelerimi açıkça ifade ederim.

25. Çevredekilerin kendimi eleştirmelerine fırsat veririm.

26. Her dersten sonra basarı ve başarısızlığımın kritiğini yaparım.

27. Olaylara değişik açılardan bakmam.

28. Karsıma çıkan zorlukları kolayca sezebilirim.

29. Okulda ve okul dışında sürekli düşünmeyi hayat tarzı haline getiririm.

30. Neyi, ne zaman, nasıl ve niçin yapacağıma dikkat etmem.

31. Herhangi bir konuda ihtiyacım olan bilgiye nasıl ulaşacağımı bilmem.

32. Problemlerin çözümünü kolaylaştırırım.

33. Herhangi bir etkinliğe başlamadan ya da karar vermeden önce nasıl yapacağımı

33. düşünür ve planlarım.

34. Yeni öğrendiklerimi önceki yaşantılarımla ilişkilendirmem.

35. Dersin sonunda konu ile ilgili düşüncelerimi yazarım.

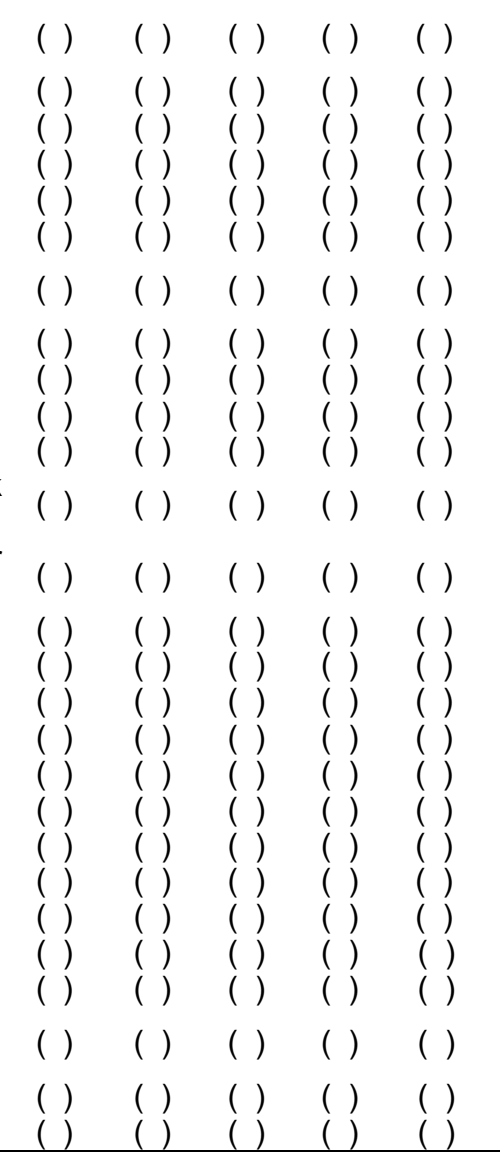

